\title{
Evaluation of Çanakkale Kilitbahir Castle in the Context of Refunctioning
}

\author{
* M.A. KUBRA DUYAR ${ }^{1}$, Dr. YASEMIN KUCUKGOK ${ }^{2}$, Mrs. FATMA MELTEM DUMAN AKYILDIZ ${ }^{3}$ \\ 1,2 \& 3 Faculty of Architecture, İstanbul Aydın University, İstanbul, Turkey \\ E mail: kubra_gobeloglu@hotmail.com ,E mail: yaseminkcgk@gmail.com E mail: fatmameltemduman@gmail.com
}

\section{ARTICLE INFO:}

\section{Article history:}

Received 15 July 2018

Accepted 23 September 2018

Available online 13 October

2018

\section{Keywords:}

Kilitbahir Castle;

Refunctioning;

Defense structure;

Museum.
This work is licensed under a Creative Commons Attribution - NonCommercial - NoDerivs 4.0. "CC-BY-NC-ND"

\begin{abstract}
A B S T R A C T
The Dardanelles Strait functions as a bridge between Biga and Gelibolu peninsulas, connecting the Aegean Sea and Marmara Sea. Many defenses have been built on the Dardanelles Strait, which have hosted many civilizations from the past to the present day, in line with the needs of the time. Kilitbahir Castle, which has a three-leaf clover plan and is located on a slope rising on the Gallipoli peninsula in the narrowest part of the Bosphorus after the conquest of Istanbul by Mehmet the Conqueror; manifests itself as a pioneering structure of the military architecture of the era with the developing artillery technology. The castle consists of a heart-shaped seven-storey inner tower in the core, the inner tower in the form of a three-leaf clover and the outer walls surrounding it. The architectural assembly of the castle is among the most aesthetic and unique among the Ottoman Castles. In terms of protecting the physical environment, it is observed that the defensive buildings which survived up to today are not adequately protected, losing their historical and architectural values. In this context, the restoration of Kilitbahir Castle dating back to Ottoman Period defense structures on the Dardanelles Strait was evaluated. Its phases throughout the process along with the current location and architecture were evaluated by using written and visual resources. European Archives, BNF Archives, Topkapı Palace Archives and Istanbul University Archives were utilized for reaching the castle engravings. In accordance with the information obtained in the historical research process, the exhibition arrangement and environment planning project of the structure, which serves as a museum, were prepared.
\end{abstract}

JOURNAL OF CONTEMPORARY URBAN AFFAIRS (2018), 2(3), 146-152. https://doi.org/10.25034/ijcua.2018.4729

www.ijcua.com

Copyright (C) 2018 Journal Of Contemporary Urban Affairs. All rights reserved.

\section{Introduction}

One of the most important actions of human existence is the concept of protection and defense. These actions led to the emergence of defense structures. They needed to be protected in order to prevent any attack from the opposite side and created defenses that they could protect themselves with. Defense structures from the past to the present day are one of the important elements forming the urban texture. The castle buildings were built

*Corresponding Author:

Faculty of Architecture, İstanbul Aydın University, İstanbul,

Turkey. E-mail address: kubra_gobeloglu@ hotmail.com 
along the periphery of the cities, on the islands near the straits or on the sea shore and near the shore. In this process, the strategic location of the city and topography also played an important role. In this context, the castles consist of circular, hexagonal or polygonal masses of bastions, or in a regular geometric form, bound together according to the topography of the city. When it comes to defense in the Turkish and Islamic cities, the buildings made up of sections such as Inner castle, Outer castle, Şehristan and Rabat come to mind. The inner castle is the main center of the defense of the area surrounded by the ramparts on the highest slope of the city, the area where the ruler or commander resides. It is the core point of the city. Outer castle surrounds the city. Şehristan is a region in the city with trade, religion, public and residential areas. Rabat is the area where there are trade functions and structures that develop around the fortress doors outside the fortifications.

Kilitbahir Castle, which was ordered to be built by Fatih Sultan Mehmed in the Ottoman Period with its own scheme, is located at the narrowest part of the Dardanelles Strait, directly opposite of the Castle Fortress to control the sea passage at Rumeli Side. Tursun Bey, one of the historians of the period, wrote that two castles facing each other were built in the narrowest part of the Bosphorus (called Eceovasi) after the conquest of Istanbul, that one of them was named Kilîdül-bahr and the other was named Sultaniye and these castles were equipped with artilleries. (1)

\section{Literature Review}

\subsection{Kilitbahir Castle Location and History}

Kilitbahir Castle is located on the Dardanelles Strait, which connects the Marmara Sea and Aegean Sea, at the edge of Malaz Hill where two opposite shores get closest with each other.

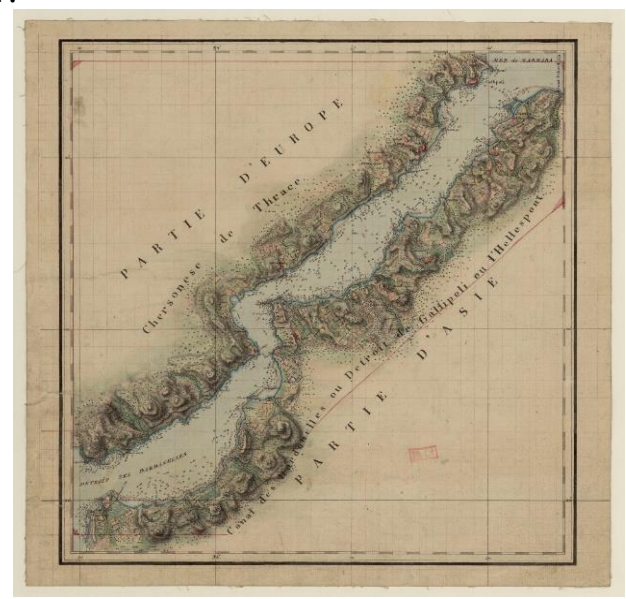

Figure 01: Map of 18th Century Dardanelles Strait, National Library of France, Map and Planning Department, GE C4074.

It was built by Mehmet the Conqueror after the conquest of Istanbul in order to keep the Bosphorus under control between 1461-1462. Having a three-leaf clover plan and located on a slope rising on the Gallipoli peninsula in the narrowest part of the Bosphorus, Kilitbahir Castle manifests itself as a pioneering structure of the military architecture of the era, integrated with the developing artillery technology.

The castle consists of a heart-shaped sevenstorey inner tower in the core, the inner tower in the form of a three-leaf clover and the outer walls surrounding it. The sea-side part of the arc-shaped outer walls did not survive. There are ten bastions on the outer walls. Two of the bastions are circular, four are triangular and four are square. There are three gates on the outer walls, two on the land and one on the sea side. The inner castle form of a clover plan formed by the joining of three circular shaped walls. The courtyards inside the walls are separated by a door. It was aimed to separate the courtyards from each other by closing the doors at the time of the attack. The inner castle has two gates, one at the sea and one at the land side. Inside the clover-shaped inner castle walls are seven-story inner towers reflecting the same geometry. The inner tower is connected to the inner castle walls with arches separating the courtyards.

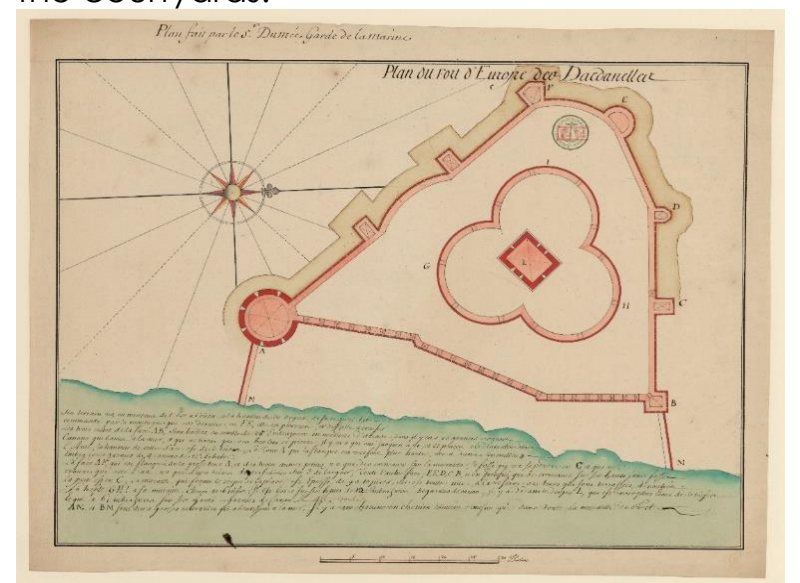

Figure 02: Gravure 01. Sr Berquin's Kilitbahir Castle Plan; National Library of France, Map and Planning Department, GE SH 18 PF 98 DIV 5 P 2

Evliya Çelebi talks about Kilitbahir Castle, which he saw in 1659, a neighborhood of tiled houses and a mosque that he named Hünkar Mosque. Furthermore, after saying that there are wheat warehouses and arsenals here, he states that there are no inns, baths and bazaars, and some artillery shells from Mora and other shells 


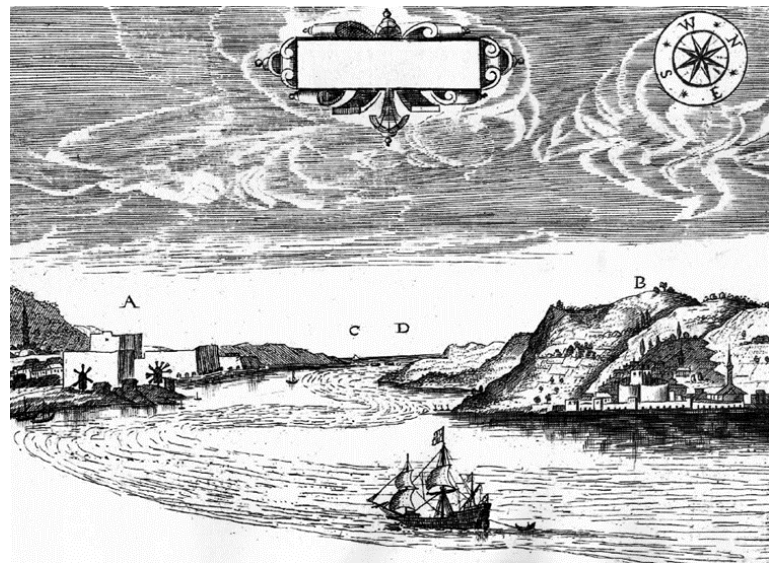

belonging to the Kanuni era are placed on the shore.

Figure 03: Gravure 02: George Sandys' Gravure dated 1621 (Ministry of Culture and Tourism - Anatolian Gravure Album)

According to Evliya Çelebi, Suleiman the Magnificent extended the Kilitbahir Castle by repairing it with the spoils taken from the Conquest of Rhodes and adding walls with the Kanuni Tower (Yellow Tower). The Dardanelles Strait, Kilitbahir and Laimenlik Castles, where George Sandys visited and engraved during his Egypt trip in 1610, behind which appears Istanbul. In the travel book published by George Sandys in 1621, titled "A relation of a journey begun An: Dom: 1610. Fovre bookes. Containing a description of the Turkish Empire, of Egypt, of the Holy Land, of the remote parts of Italy, and ilands adioyning", the inner castle from the era of Mehmet the Conqueror and walls and Kanuni Tower built in the era of Suleiman the Magnificent can be observed in the Kilitbahir Castle, marked as "B".

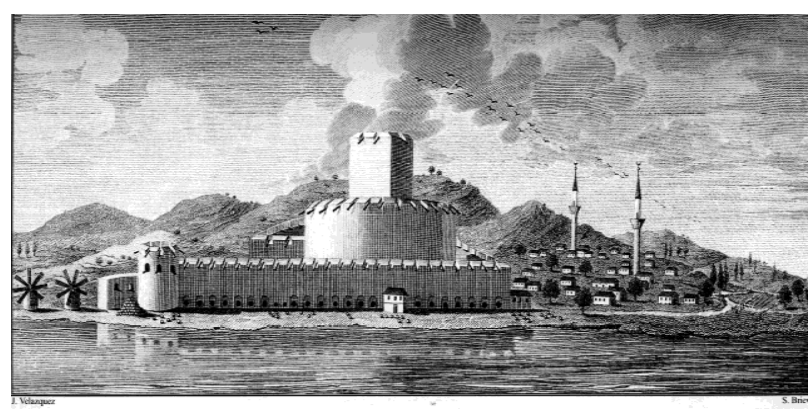

Figure 04: Gravure 03: Joseph Moreno's Gravure dated 1790 (Ministry of Culture and Tourism - Anatolian Gravure Album)

Kilitbahir gravures inside the tower, the inner castle and the Kanuni Tower (Yellow Tower) and the outer walls are found in the work "Viage á Constantinopla, en el año de 1784 (journey to Istanbul in 1784)" prepared by José María Moreno (Joseph Moreno).

The last architectural formation of Kilitbahir Castle reached to the day-time was completed when the Namazgah Redoubt was rebuilt between 1893-1894. In the works carried out on this date, the door and the wall located on the sea shore in the east direction of the castle, the wall, the shrine, the headquarters building and the door were added to the south side of the bay, surrounding Namazgah Redoubt. The wall of the inner castle in the sea direction and the port gate were destroyed during this period. Namazgah Redoubt, walls and castle gates were added to the Kilitbahir Castle during the reign of Abdülhamit II, finalizing the shape of it.

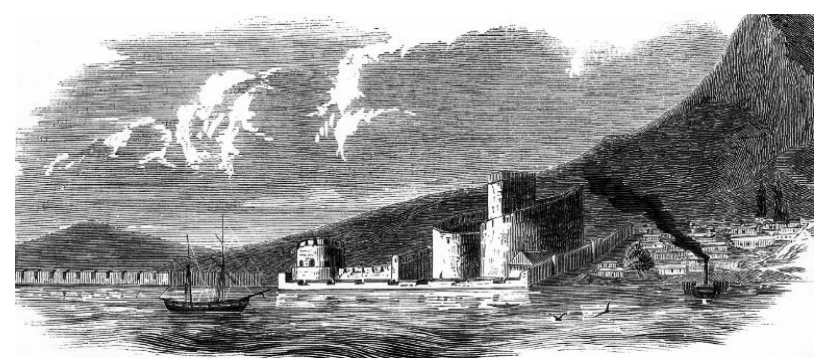

Figure 06: Gravure 04: Gravure of Kilitbahir Castle and Namazgah Redoubt dated 1853 titled "L'lllustration: Journal universel".

Kilitbahir Castle was depicted close to its present appearance. The walls in front of the inner castle were not drawn first in this gravure. From the building traces reaching today around the inner castle, the building at the shore to the north are observed in this gravure.

\section{Material and Method}

Kilitbahir Castle has an important place among the defense structures in Çanakkale the period of its construction, its strategic location, and its architecture. The fact that location of the Historical Gallipoli Peninsula is within the trip route has caused the Castle to increase the number of tourists day by day. The castle has undergone many repairs until reaching today, but it has not been able to gain a function together with its architectural texture and its surroundings and that caused it to have a structure that only exhibits its own architecture. Due to these reasons, environmental planning and exhibition were needed.

European Archives, BNF Archives, Topkapı Palace Archives and Istanbul University Archives were utilized for the researches conducted to draw the project. In accordance with the information obtained in the historical research process, the exhibition arrangement and environment planning project of the structure, which serves as "Ottoman Castle Museum", were prepared. 


\subsection{Sampling Area}

The castle is situated on a slope in the narrowest part of the Dardanelles Strait. It is located opposite the Çimenlik Castle on the strait, which was built during the same period.

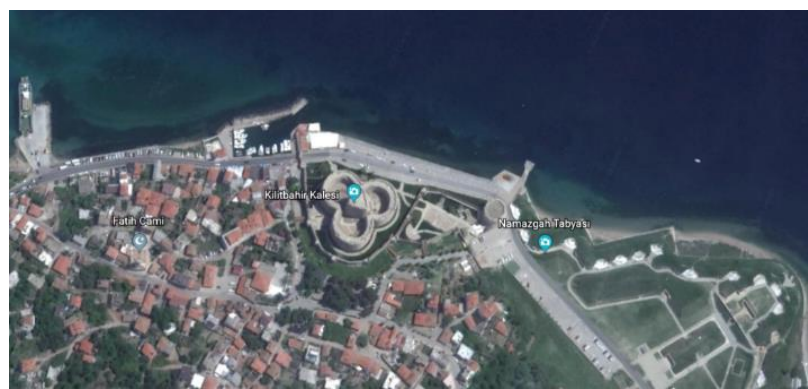

Figure 07: Kilitbahir Castle, $40.15^{\circ} \mathrm{N}, 26.38^{\circ} \mathrm{E}$ coordinates

The refunctioning of Kilitbahir Castle considered altogether with the inner tower built during the reign of Mehmed the Conqueror, the Yellow
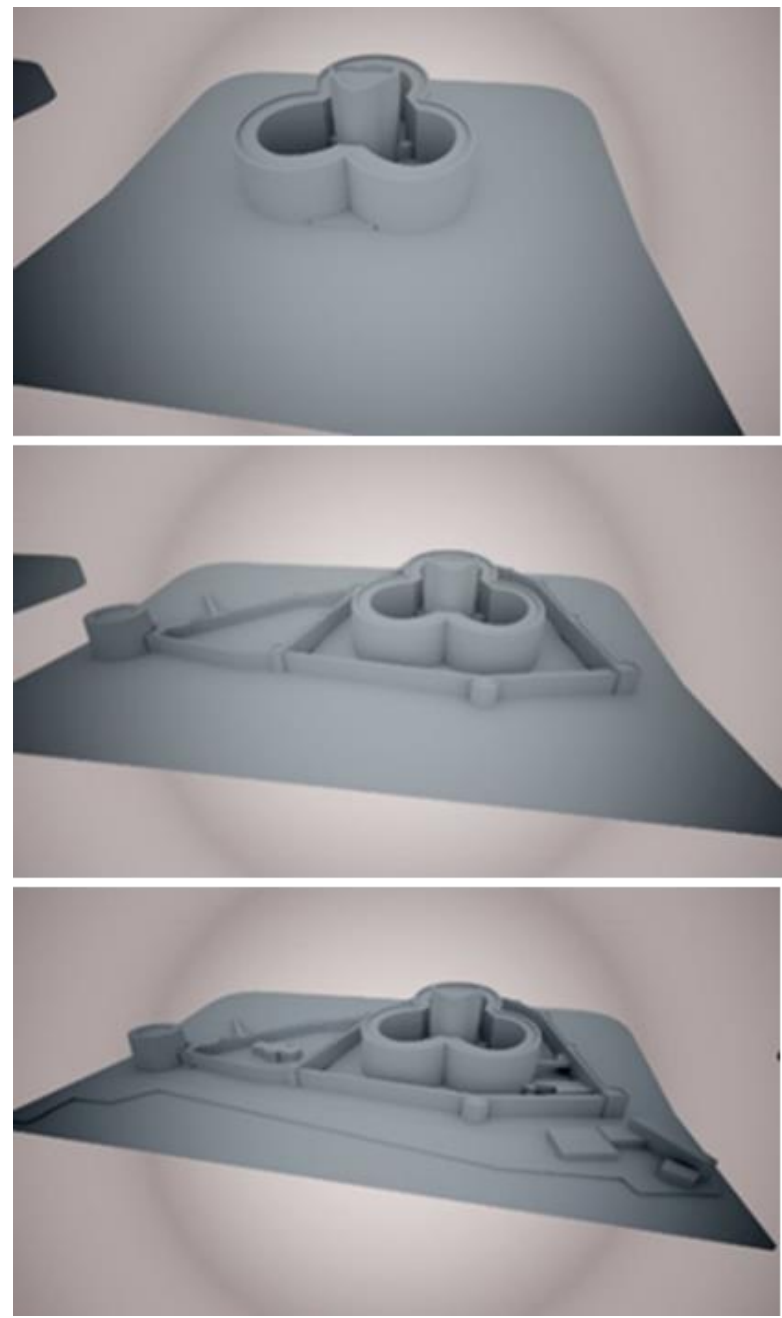

Tower built by Suleiman the Magnificent, the Late Period Courtyard and the additions made in Abdülhamit Era.

Figure 08: Era of the Conqueror (Inner Tower) - Era of Suleiman the Magnificent (Yellow Tower, Late Period Courtyard) - Era of Abdülhamit (Military Factory, Shrine), K. Duyar.

\subsection{Method}

European Archives, BNF Archives, Topkapı Palace Archives and Istanbul University Archives were utilized for reaching the castle engravings in the historical researches conducted during the refunctioning process of Kilitbahir Castle. In accordance with the information obtained, it is envisaged that the castle museum function will be re-functioned together with a script describing Castle Life in the Era of Mehmet the Conqueror.

\section{Refunctioning the Kilitbahir Castle}

In the entrance to the castle, the circulation is planned as two separate tours, short and long. Short Tour:

- Yellow Tower / General Museum Presentation,

- Demo Museum / Disabled, Old, Sick, Tired Visitors,

- Amphitheater / Greeting and Museum Activity Area,

\section{SIRKÜLASYON, KISA TUR}

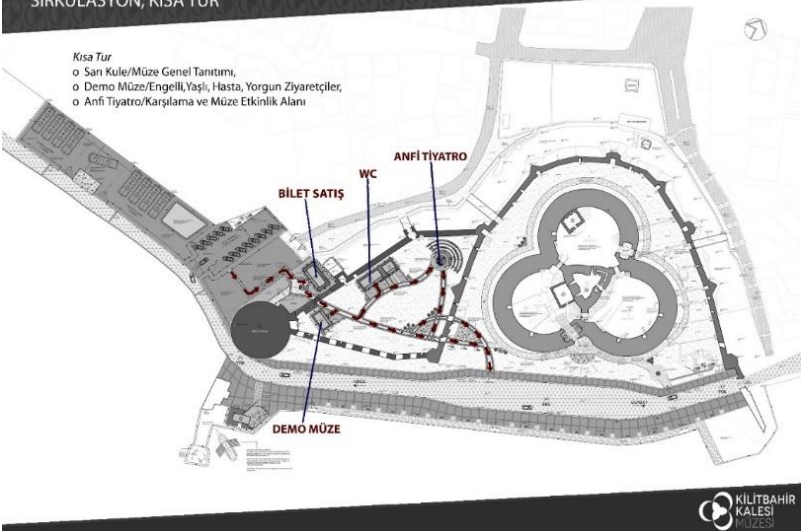

Figure 09: Kilitbahir Castle Site Plan-Short Tour Route, $\mathrm{K}$. Duyar.

Long Tour:

- Yellow Tower / General Museum Presentation,

- Demo Museum / Disabled, Old, Sick, Tired Visitors,

- Amphitheater / Greeting and Museum Activity Area,

- Piri Reis Section,

- Multivision Section,

- Temporary Exhibition Section,

- Tower Museum

2 separate tours as specified above were offered where visitors would be able to visit the outdoor and exhibition spaces without leaving the script, to easily participate in museum activities along the route, and to avoid unrestrained travels within the area. 


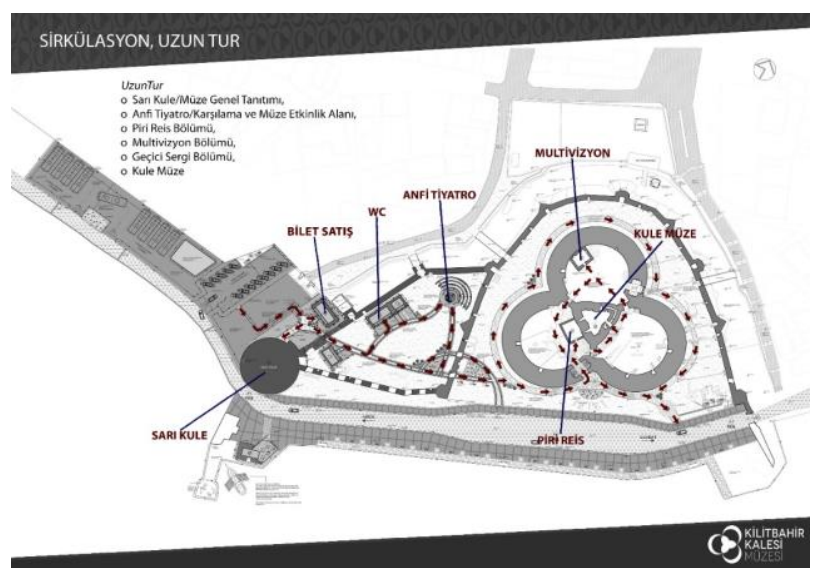

Photo 10: Kilitbahir Castle Site Plan-Long Tour Route, K. Duyar.

\subsection{Entrance Area (Parking Lot, Museum Entrance, Ticket Sales)}

By taking the visitor from a single point with "1C Entrance" close to the car park area and in line with the exhibition arrangement scenario; 2 separate tours, Long Tour and Short Tour, were offered where visitors would be able to visit the outdoor and exhibition spaces without leaving the script, to easily participate in museum activities along the route, and to avoid unrestrained travels within the area.

\subsection{Yellow Tower}

The Yellow Tower is the first place of the trip route. For this reason, the exhibition project is planned as the "General Presentation Area of the Ottoman Calendars", which is important for the visitor's perception of the museum concept and scenario in a complete and accurate way. In this place, a brief introduction of the visit is offered in a thematic order about the general presentation of Ottoman monuments, architectural structures, castle structure, castle equipment, organizational structure, commercial life effects and defense strategies.

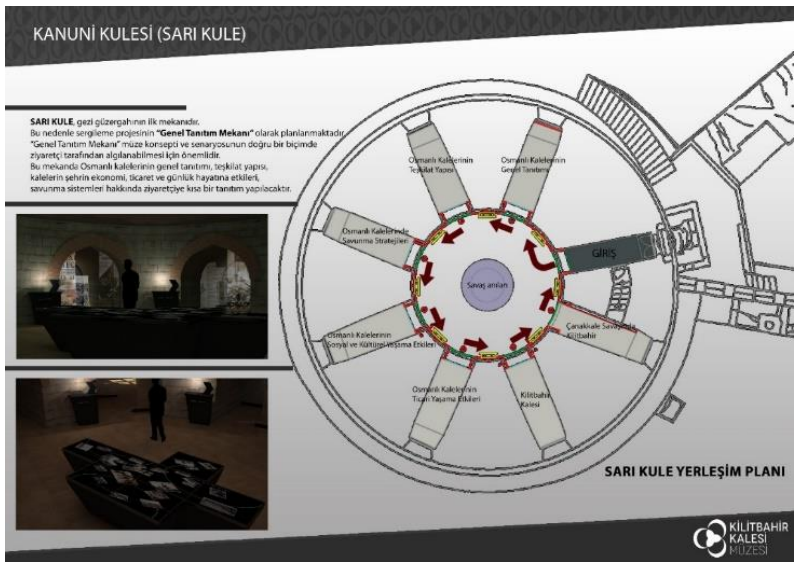

Photo 11: Yellow Tower Plan, K. Duyar.
In the Yellow Tower, in addition to interactive presentations within a thematic order about the general presentation of Ottoman monuments, architectural structures, castle structure, castle equipment, organizational structure, commercial life effects and defense strategies, the subject is depicted with niche transparent projection curtains and impersonations on the subject.

\subsection{Demo Museum}

The physical conditions and historical texture of the Tower Museum and the Yellow Tower, two of the most important places of the exhibition arrangement project, make it impossible for the handicapped, elderly, sick and young children to easily complete the sightseeing tour. Since it will not be possible to remove the negative consequences of the physical obstacles at all times in the registered structures, Demo Museum will be prepared in order to present the exhibited works and the scenario to the disabled visitors who cannot visit the museum. The demo museum features virtual tour, diaroma and touchscreen table. One of the most important elements of the Demo Museum is the capability of the visitors whose health and physical condition do not allow them to tour the museum to see the museum and its surroundings in a virtual environment with virtual headings and in 360 degrees while sitting. The visitors will be informed with the embossed writings on the walls for the visually handicapped visitors and they will be able to touch and examine the identical replica of several works to be exhibited in the museum. Demo Museum is prepared to serve visitors who have to leave without seeing the building which is kept closed due to restoration and repair. Demo Museum is especially important as it is a first-time application that will be carried out for the museums that are compulsory kept closed.

\subsection{Museum Management / Administration}

When scrutinized in a museological perspective, it is vitally important to have a control over the museum area and to be accessible all the time for an effective museum management. Therefore, the "Museum Management / Administration" structure is positioned in front of the walls at the entrance of the area to ensure museum visitors and visitors coming for any business easily and conveniently reach the management unit and that the security of the area can be maintained quickly and efficiently in emergency or routine controls. 


\subsection{Piri Reis Section}

Right next to the tower inside the castle is the exhibition of Piri Reis's life and its most important work, Kitab-ı Bahriye and world map, according to modern museology. In the section, the 3D silicon sculpture animation area, the video display area, the same edition of the original of the Kitab-ı Bahriye as well as the Turkish version, the exhibition of astrolabe, compass and divider reproductions and the map installation showing the similarities between the world map of Piri Reis and today's world map that utilizes the enhanced reality software.

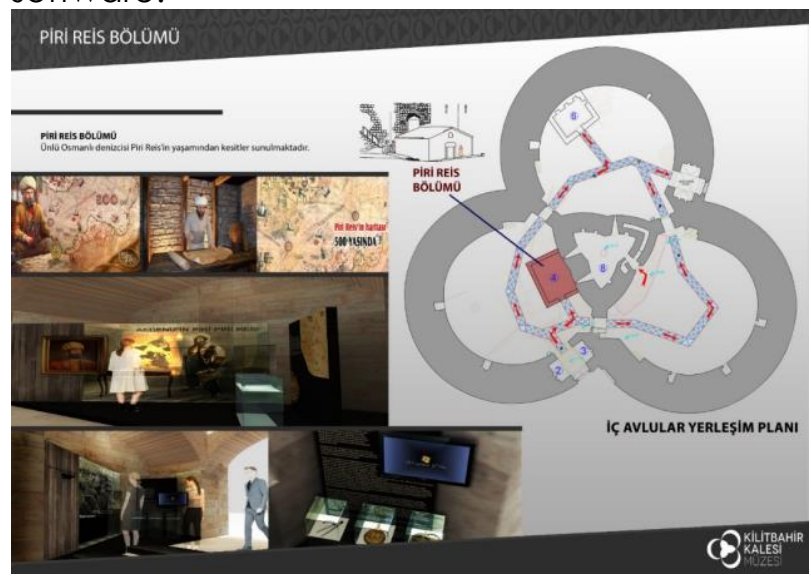

Photo 12: Piri Reis Section Plan, K. Duyar.

\subsection{Multivision (Bath Structure) and Temporary Exhibition Area}

The "Multivision Section" located in the bath structure of the project has been used as a Temporary Exhibition Area on special days as well as the stated function. Our greatest goal should be to bring our renewed and developing museums to international museum standards with the understanding of contemporary museology. In this context, the exhibition arrangement project should not be considered independent of museum planning. All sections and functions, which should be included for an accurate, scientific and contemporary museum, must be included in the planning.

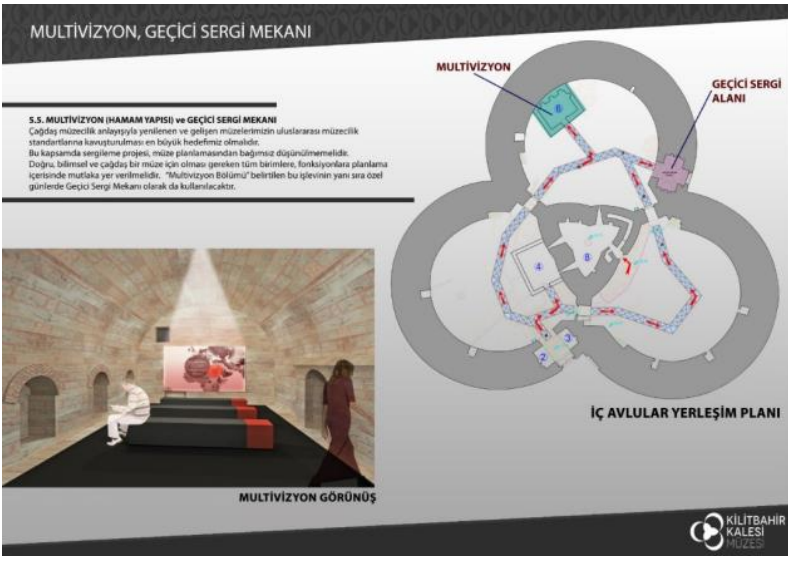

Figure 13: Multivision-Temporary Exhibition Area Plan, $\mathrm{K}$. Duyar.

\subsection{Tower Museum}

In the scope of the exhibition arrangement project of the 6-storey tower structure which is functioned as a Tower Museum, life in Kilitbahir Castle is explained. In the ground floor, the space is divided to three different eras since the construction of the Castle, namely Era of Mehmet the Conqueror, Era of Suleiman the Magnificent and Era of Abdülhamit. Defense, catering, commerce and worship are depicted in Floors 1, 2, 3 and 4. On the 5th floor, it is stipulated to exhibit the works that were excavated during the excavation in the Castle.

\section{Conclusion}

Kilitbahir Castle is a very important place in terms of architecture and art history among the castles in the Era of Mehmed the Conqueror. Having a planned structure of a three-leafed clover, the castle consists of a seven-storey inner tower in the core, the inner tower in the form of a three-leaf clover and the outer walls surrounding it. The architectural assembly of the castle is among the most aesthetic and unique among the Ottoman Castles. The sea-side part of the arc-shaped outer walls did not survive. There are ten bastions on the outer walls. Two of the bastions are circular, four are triangular and four are square. There are three gates on the outer walls, two on the land and one on the sea side.

The Castle is one of the important defenses in terms of both its period and its strategic position. The Historical Gallipoli Peninsula is among the travel routes that increase the number of tourists every day. The structure, which is a center of attention with its history and culture, should be refunctioned and should survive. For this purpose, the structural equipment has been functioned without damaging the present structure of the castle, and support has been provided with the 
demounting structures in areas where it is not sufficient. The original architectural texture of the castle and the areas that have been rendered functional by its surroundings will be taken for a longer period of preservation and transfer of the past to future generations.

\section{Acknowledgement}

This research did not receive any specific grant from funding agencies in the public, commercial, or not-for-profit sectors.

\section{References}

Ozguven, H. B. (1997). Barut ve Tabya: Rönesans Mimarisi Bağlamında Fatih Sultan Mehmed Kaleleri [Barut and Tabya: Fatih Sultan Mehmed Castles in the Context of Renaissance Architecture], Yayınlanmamıs Doktora Tezi, İstanbul Teknik Üniversitesi Sosyal Bilimler Enstitüsü, İstanbul. Availible at: http://kaynakca.hacettepe.edu.tr/eser/208 683/barut-ve-tabya-ronesans-mimarisibaglaminda-fatih-sultan-mehmed-kaleleri

Nesri, M. (1957). Kitab-ı Cihannüma [BookJihannüma], Cilt II, der F.R. Unat ve M.A. Köymen, Türk Tarih Kurumu Yayınları, Ankara. Availible at:

https://www.kitapyurdu.com/kitap/kitabicihannuma-nesri-tarihi-2-cilttakim/361759.html

Tursun Bey (2000), Tarihi Osmanlı Encümeni Mecmuası, $\quad$.67 (1). Availible at: http://tarihvemedeniyet.org/201 1/02/tarihiosmani-encumeni-mecmuasi.html

Nisancı Mehmed (Paşa). (1949), "Tevarih-i El Sultan El-Osmaniyye [the history of Sultan ElOsmaniye], Osmanlı Tarihleri, cilt:I, çev. İbrahim Hakkı Konyalı, der. N. Atsız Çiftçioğlu, İstanbul. Availible at https://www.google.com/urle sa=t\&rct=j\&q= \&esrc $=s \&$ source $=$ web\&cd $=1 \& c a d=r j a \& u a c t$ $=8 \&$ ved $=2 a h U K E w j z t P G p$ anfAhVKIlsKHVz4Bz gQFjAAegQIAxAC\&url=http\%3A\%2F\%2Fsuta d.selcuk.edu.tr\%2Fsutad\%2Farticle\%2Fdownl oad\%2F405\%2F395\&usg=AOVVaw3ax8A4hYilAuHOZLOR33M

Francis, Y. (1992). Şehir Düştü-Bizans Tarihçi Francis' den Istanbul' un Fethi [The city fell from the Byzantine historian Francis from Istanbul], çev. Kriton Dinçmen, Illetişim Yayınları, istanbul. Availible at: https://www.nadirkitap.com/sehir-dustubizans-li-tarihci-francis-den-istanbul-un-fethifrancis-yeorgios-kitap 1 1476231.html

Gravürlerle Türkiye [Engraving with Turkey , Anadolu]. (2002) , Mustafa Sevim, Kültür Bakanlığı Yayınları, Cilt I Ankara. Availible at https://www.nadirkitap.com/gravurlerle- turkiye-giysiler-portreler-2-cilt-takim-mustafasevim-kitap7881236.html

Utkular i. (1954). Çanakkale Boğazında Fatih Kaleleri [Fatih Castles in the Dardanelles], ITÜ Yayınları, İstanbul,

Acıoğlu, Y. (2006). Çanakkale Boğazı'ndaki Kaleler [Castles in the Dardanelles], Yüksek Lisans Tezi, 18 Mart Üniversitesi, Fen Bilimleri Enstitüsü, Çanakkale. Availible at http://kaynakca.hacettepe.edu.tr/eser/372 41015/canakkale-bogazi-ndaki-kaleler

Piri Reis. (1973). Kitab-ı Bahriye [Denizcilik Kitabı], Haz. :Y. Senemoğlu, C.I-II.86, İstanbul. Availible at https://www.academia.edu/4050817/Piri_Re is in Kitab-

\%C4\%Bl_Bahriye sine g\%C3\%B6re XVI. Y\%C 3\%BCzy\%C4\%Bllda Karada\%C4\%9F K\%C4\% Bly\%C4\%Bllar\%C4\%B1.----

Coasts of Montenegro in 16th century in the Kitab-\%C4\%B1_Bahriye_Piri_Reis

Askıdil. A. (1998), Şehir ve Savunması [City and Defense], Türk Tarih Kurumu Yayınları, Ankara. Availible at https://www.nadirkitap.com/sehir-vesavunmasi-askidil-akarca-kitap2264164.html 